\title{
ANALISIS TINGKAT KESIAPSIAGAAN BENCANA GEMPA BUMI di MTS M TRUCUK DAN MTS M 10 WEDI KABUPATEN KLATEN
}

\author{
Bening Ati Nastiti ${ }^{1}$, Roby Hermawan ${ }^{2}$ Kirana Amurwa Kusuma ${ }^{3}$, Edelyn \\ Febilia Danta ${ }^{4}$, Ramadhani Rizkyandri ${ }^{5}$, Zaid Ali Wardana ${ }^{6}$ \\ ${ }^{1,2,3,4,5,6}$ Program Studi Pendidikan Geografi \\ Fakultas Keguruan dan Ilmu Penididikan, Universitas Muhammadiyah Surakarta \\ J1. A.Yani, Mendungan, Pabelan, Kecamatan Kartasura, Kabupaten Sukoharjo, Jawa Tengah \\ Alamat e-mail: ${ }^{1}$ beningati98@gmail.com
}

\begin{abstract}
Abstrak
Penelitian ini bertujuan untuk mengetahui tingkat kesiapsiagaan terhadap bencana gempa bumi di MTs M Trucuk dan MTs M 10 Wedi. Metode penelitian menggunakan deskriptif kuantitatif dengan sampel penelitian sebanyak 246 siswa dan 26 guru ditentukan dengan teknik purposive sampling. Hasil penelitian menunjukkan kesiapsiagaan secara keseluruhan dari kedua sekolah memiliki hasil yang hampir sama dari guru maupun siswa pada keseluruhan parameter. Kesiapsiagaan guru di dua sekolah dalam kategori ketercapaian tinggi dilihat dari angka pada grafik kesiapsiagaan guru dari kedua sekolah, MTs M Trucuk dan MTs M 10 Wedi. Sedangkan kesiapsiagaan siswa di kedua sekolah dalam kategori ketercapaian sedang, hal itu dapat dilihat dari grafik kesiapsiagaan siswa dari kedua sekolah hasil perhitungan data kuisioner yang sudah diisi oleh siswa dan guru kedua sekolah.
\end{abstract}

Kata Kunci: bencana; mitigasi; tingkat kesiapsiagaan;

Abstract

This study aims to determine the level of preparedness for earthquake disasters in MTs M Trucuk and MTs M 10 Wedi. The research method uses quantitative descriptive research with a sample of 246 studens and 26 teachers determined by purposive sampling technique. The results showed overall preparednessof the two schools had almost the same results from teachers and students in all parameters. Teacher readiness in two schools in the high achievement category can be seen from the figures on the teacher readiness chart from the two schools, MTs M Trucuk and MTs M 10 Wedi. While the preparedness of students from both schools the results of questionnaire data calculations that have been filled out by students and teachers of both schools.

Keywords: disaster; mitigation; level of preparedness;

\section{PENDAHULUAN}

Bencana alam yang terjadi selama beberapa tahun terakhir membuat Indonesia menjadi negara yang cukup progresif dalam penanggulangan bencana ke depan. Bencana alam merupakan peristiwa yang mengancam dan mengganggu masyarakat yang disebabkan oleh faktor alam maupun non-alam, sehingga menimbulkan adanya korban jiwa, kerusakan lingkungan, kerugian harta benda, dan dampak psikologis. (Undang-undang No.24 Tahun 2007). Bencana alam yang sering terjadi di Indonesia salah satunya yaitu gempa bumi. Salah satu faktor yang 
menyebabkan Indonesia sebagai negara yang mempunyai potensi gempa terbesar di dunia dikarenakan Indonesia terletak antara tiga pertemuan lempeng yaitu lempeng Eurasia, lempeng Indo-Australia, dan lempeng Pasifik yang sewaktu-waktu dapat bergerak dan menimbulkan patahan.

Jawa Tengah bagian selatan merupakan daerah rawan gempa bumi. Menurut peta rawan bencana gempa bumi Kabupaten Klaten tahun 2011-2031 menunjukkan bahwa Kecamatan yang masuk dalam daerah rawan gempa bumi yaitu Kecamatan Prambanan, Kecamatan Gantiwarno, Kecamatan Wedi, Kecamatan Bayat. Berdasarkan data BNPB dalam kategori Indeks Rawan Bencana Single Hazard Kabupaten/Kota, Klaten menempati rangking 2 tingkat nasional. Bencana gempa bumi pernah terjadi di Klaten pada tanggal 27 Mei 2006 yang telah menimbulkan banyak kerugian dan korban jiwa (Kuncoro, 2006 dalam Kresnadewara, dkk). Gempa bumi tersebut mengguncang Kabupaten Klaten dan sekitarnya dengan kekuatan 6,3 skala ritcher dengan pusat gempa yang terletak di daerah Yogyakarta bagian selatan.

Sekolah merupakan salah satu pemangku kepentingan untuk mengurangi risiko bencana. Untuk mengetahui kerentanan dan kesiapsiagaan sekolah dalam tujuan mengurangi risiko bencana di sekolah, maka perlu diadakannya analisis tingkat kerentanan dan kesiapsiagaan siswa sekolah terhadap bencana. Kerentanan adalah sebuah konsep yang berkembang dari ilmu-ilmu sosial yang digunakan sebagai titik awal untuk menilai pengurangan risiko.

Kesiapsiagaan merupakan kegiatan yang dilakukan untuk menantisipasi bencana. Kunci utama dari kesiapsiagaan adalah pengetahuan. Dari pengetahuan yang dimiliki akan berpengaruh terhadap kepedulian dan sikap untuk siap siaga dalam mengantisipasi suatu bencana. Kesiapsiagaan merupakan salah satu elemen penting dari kegiatan pengurangan resiko bencana (Firmansyah, 2014). Analisis kapasitas dan kesiapsiagaan sekolah bertujuan untuk mengkaji dan menemukan kemampuan murid sekolah, fasilitas sekolah, dan pihak lain untuk mengurangi risiko bencana pada murid.

Tingkat kesiapsiagaan sekolah perlu diuji untuk mengetahui tingkat pemahaman siswa terhadap risiko bencana agar mengurangi kerugian dan korban 
jiwa saat bencana. Penelitian ini akan dilakukan di MTs M Wedi dan MTs M Trucuk karena letak sekolah yang berada pada daerah rawan gempa bumi.

\section{METODE}

Penelitian ini menggunakan pendekatan kuantitatif. Penelitian ini dilakukan di MTs M 10 Wedi dan MTs M Trucuk, Kabupaten Klaten. Sampel yang diambil dalam penelitian sebanyak 246 siswa dan 26 guru. Teknik sampling yang kami gunakan adalah purposive sampling. Metode yang digunakan yaitu metode observasi, penyebaran kuesioner (angket) dan dokumentasi.

Analisis deskriptif digunakan untuk mendeskripsikan tingkat pengetahuan siswa. Pengukuran pada variabel diungkap dengan memberikan skor 1 untuk sangat tidak setuju, 2 untuk tidak setuju, 3 untuk setuju, 4 untuk sangat setuju. Perhitungan indeks dihitung dengan menggunakan:

$$
\begin{aligned}
& \text { Indeks Perparameter }=\frac{\text { Jumlah Skor Rill Perparameter }}{\text { Skor Maksimum Parameter }} \times 100 \\
& \text { Indeks Perindividu }=\frac{\text { Jumlah Skor Rill Parameter Perindividu }}{\text { Skor Maksimal Seluruh Parameter }} \times 100
\end{aligned}
$$

Klasifikasi untuk mengukur kesiapsiagaan siswa MTs M 10 Wedi dan MTs M Trucuk dalam menghadapi bencana gempa bumi dapat diketahui melalui:

\section{Tabel 1. Nilai Indeks Ketercapaian Kesiapsiagaan}

\begin{tabular}{|c|l|c|}
\hline No & \multicolumn{1}{|c|}{ Nilai Indeks } & Kategori \\
\hline 1 & $67-100$ & Ketercapaian Tinggi \\
\hline 2 & $34-66$ & Ketercapaian Sedang \\
\hline 3 & $0-30$ & Ketercapaian Rendah \\
\hline
\end{tabular}

Sumber: LIPI, Panduan mengukur tingkat kesiapsiagaan masyarakat dan komunitas sekolah

Analisis deskriptif digunakan untuk mendeskripsikan tingkat pengetahuan guru. Pengukuran pada variabel diungkap dengan memberikan skor 1 untuk ya, 2 untuk tidak. Perhitungan indeks dihitung dengan menggunakan: 


$$
\begin{aligned}
& \text { Indeks Perparameter }=\frac{\text { Jumlah Skor Rill Perparameter }}{\text { Skor Maksimum Parameter }} \times 100 \\
& \text { Indeks Perindividu }=\frac{\text { Jumlah Skor Rill Parameter Perindividu }}{\text { Skor Maksimal Seluruh Parameter }} \times 100
\end{aligned}
$$

Klasifikasi untuk mengukur kesiapsiagaan guru MTs M 10 Wedi dan MTs M Trucuk dalam menghadapi bencana gempa bumi dapat diketahui melalui:

Tabel 2.Nilai Indeks Ketercapaian Kesiapsiagaan

\begin{tabular}{|c|l|c|}
\hline No & \multicolumn{1}{|c|}{ Nilai Indeks } & Kategori \\
\hline 1 & $67-100$ & Ketercapaian Tinggi \\
\hline 2 & $34-66$ & Ketercapaian Sedang \\
\hline 3 & $0-30$ & Ketercapaian Rendah \\
\hline
\end{tabular}

\section{HASIL DAN PEMBAHASAN}

\section{Kesiapsiagaan Siswa Perparameter}

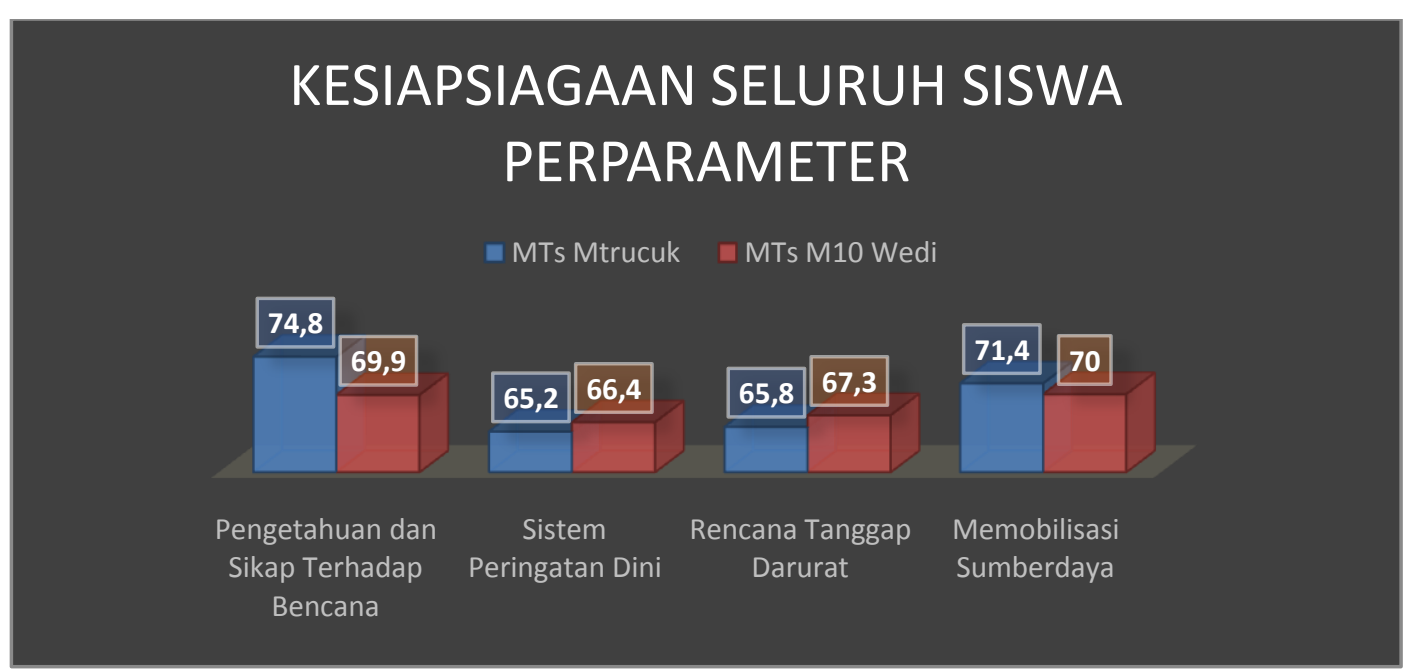

\section{Gambar 1.Grafik Kesiapsiagaan Seluruh Siswa Perparameter}

Gambar 1. mendeskripsikan tingkat kesiapsiagaan siswa per parameter yang terdiri dari indeks parameter pengetahuan dan sikap terhadap bencana, sistem peringatan dini, rencana tanggap darurat, memobilisasi sumberdaya di MTs M 
Trucuk dan MTs M 10 Wedi tahun 2019. Pada indeks pengetahuan dan sikap terhadap bencana siswa MTs M Trucuk memiliki nilai 74,8\% dan siswa MTs M 10 Wedi memiliki nilai 69,9\%. Dari indeks tersebut MTs M Trucuk memiliki nilai yang lebih tinggi dibandingkan dengan siswa MTs M 10 Wedi, dengan selisih nilai sebesar 4,9\%. Pada indeks sistem peringatan dini, siswa MTs M 10 Wedi memiliki nilai 66,4\% dan siswa MTs M Tucuk memiliki nilai 65,2\%. Pada indeks teresebut MTs M 10 Wedi memeiliki nilai yang lebih tinggi dibandingkan dengan siswa MTs M Trucuk, dengan selisih nilai sebesar 1,2\%. Pada indeks rencana tanggap darurat siswa MTs M 10 Wedi memiliki nilai 67,3\% dan siswa MTs M Trucuk memeiliki nilai 65,8\%. Pada indeks tersebut MTs M 10 Wedi memiliki nilai yang lebih tinggi dibandingkan dengan siswa MTs M Trucuk, dengan selisih nilai sebesar 1,5\%. Pada indeks memobilisasi sumberdaya siswa MTs M Trucuk memiliki nilai 71,4\% dan siswa MTs M 10 Wedi memiliki nilai 70\%. Pada indeks tersebut MTs M Trucuk yang lebih tinggi dibandingkan siswa MTs M 10 Wedi, dengan selisih nilai sebesar 1,4\%. Dari grafik tersebut dapat disimpulkan bahwa tingkat kesiapsiagaan seluruh siswa per parameter memiliki kategori baik pada parameter tertentu. MTs M Trucuk unggul pada parameter pengetahuan dan sikap terhadap bencana dan memobilisasi sumberdaya dan MTs M 10 Wedi unggul pada parameter sistem peringatan dini dan rencana tanggap darurat.

\section{Kesiapsiagaan Siswa Keseluruhan}

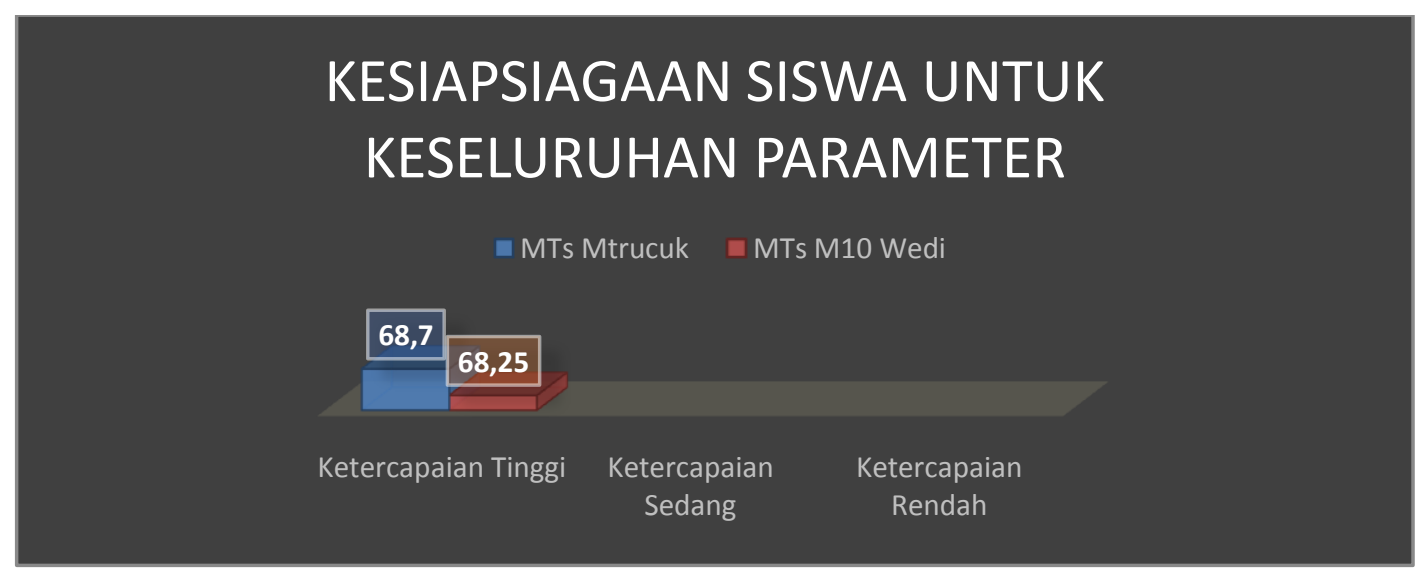

Gambar 2. Grafik Kesiapsiagaan Siswa untuk Keseluruhan Parameter 
Gambar 2. mendeskripsikan kesiapsiagaan siswa untuk keseluruhan parameter di MTs M Trucuk dan MTs M 10 Wedi tahun 2019. Kesiapsiagaan siswa memiliki ketercapaian baik dengan jumlah rata-rata yang berbeda. Kesiapsiagaan siswa MTs M Trucuk memiliki nilai 68,7\% dan MTs M 10 Wedi memiliki nilai 68,25\%. MTs M Trucuk memiliki nilai yang lebih tinggi dibandingkan dengan kesiapsiagaan siswa MTs M Trucuk, dengan selisih nilai sebesar 0,45\%. Dengan demikian sekolah siaga yang ada dapat memberikan dampak yang positif terhadap kesiapsiagaan siswa yang ada.

\section{Kesiapsiagaan Guru Perparameter}

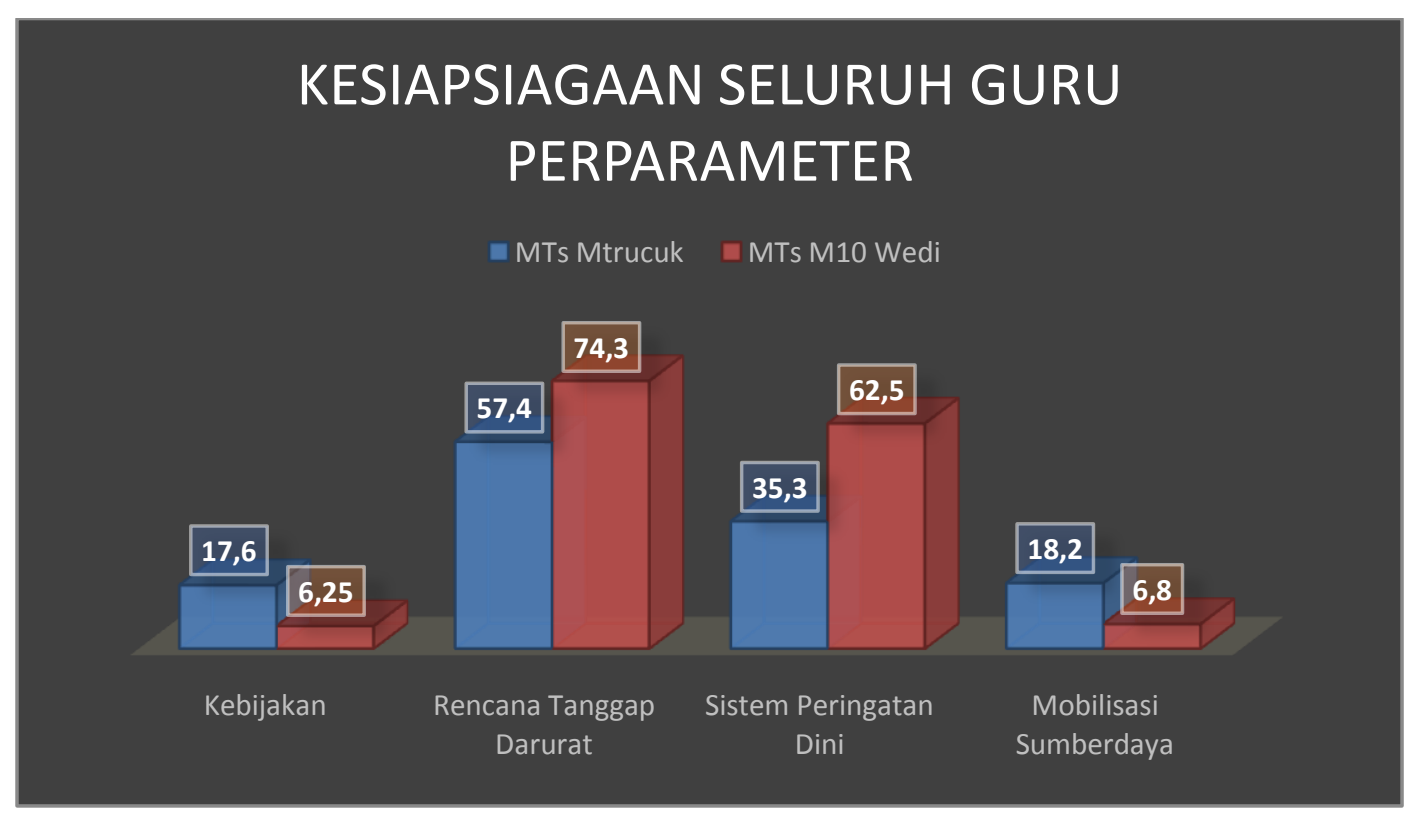

Gambar 4. Grafik Kesiapsiagaan Seluruh Guru Perparameter

Gambar 4. mendeskripsikan tingkat kesiapsiagaan seluruh guru perparameter yang terdiri dari indeks parameter kebijakan, rencana tanggap darurat, sistem peringatan dini, memobilisasi sumberdaya tahun 2019. Pada indeks kebijakan, guru MTs M Trucuk memiliki nilai 17,6\% dan guru MTs M 10 Wedi memiliki nilai 6,25\%. Pada indeks tersebut guru MTs M Trucuk memiliki nilai yang lebih tinggi dibandingkan dengan guru MTs M 10 Wedi, dengan selisih nilai sebesar 11,35\%. Pada indeks rencana tanggap darurat, guru MTs M 10 Wedi memiliki nilai 74,3\% dan guru MTs M Trucuk memiliki nilai 57,4\%. Pada indeks 
tersebut guru MTs M 10 Wedi memiliki nilai yang lebih tinggi dibandingkan dengan guru MTs M Trucuk, dengan selisih nilai sebesar 16,9\%. Pada indeks sistem peringatan dini guru MTs M 10 Wedi memiliki nilai 62,5\% dan guru MTs M Trucuk memiliki nilai 35,3\%. Pada indeks tersebut guru MTs M 10 Wedi memiliki nilai yang lebih tinggi dibandingkan dengan guru MTs M Trucuk, dengan selisih nilai sebesar 27,2\%. Pada indeks mobilisasi sumberdaya guru MTs M Trucuk memiliki nilai 18,2\% dan guru MTs M 10 Wedi memiliki nilai 6,8\%. Pada indeks tersebut guru MTs Trucuk memiliki nilai yang lebih tinggi dibandingkan dengan guru MTs M 10 Wedi, dengan selisih nilai sebesar 11,4\%.

\section{Kesiapsiaagaan Guru Keseluruhan}

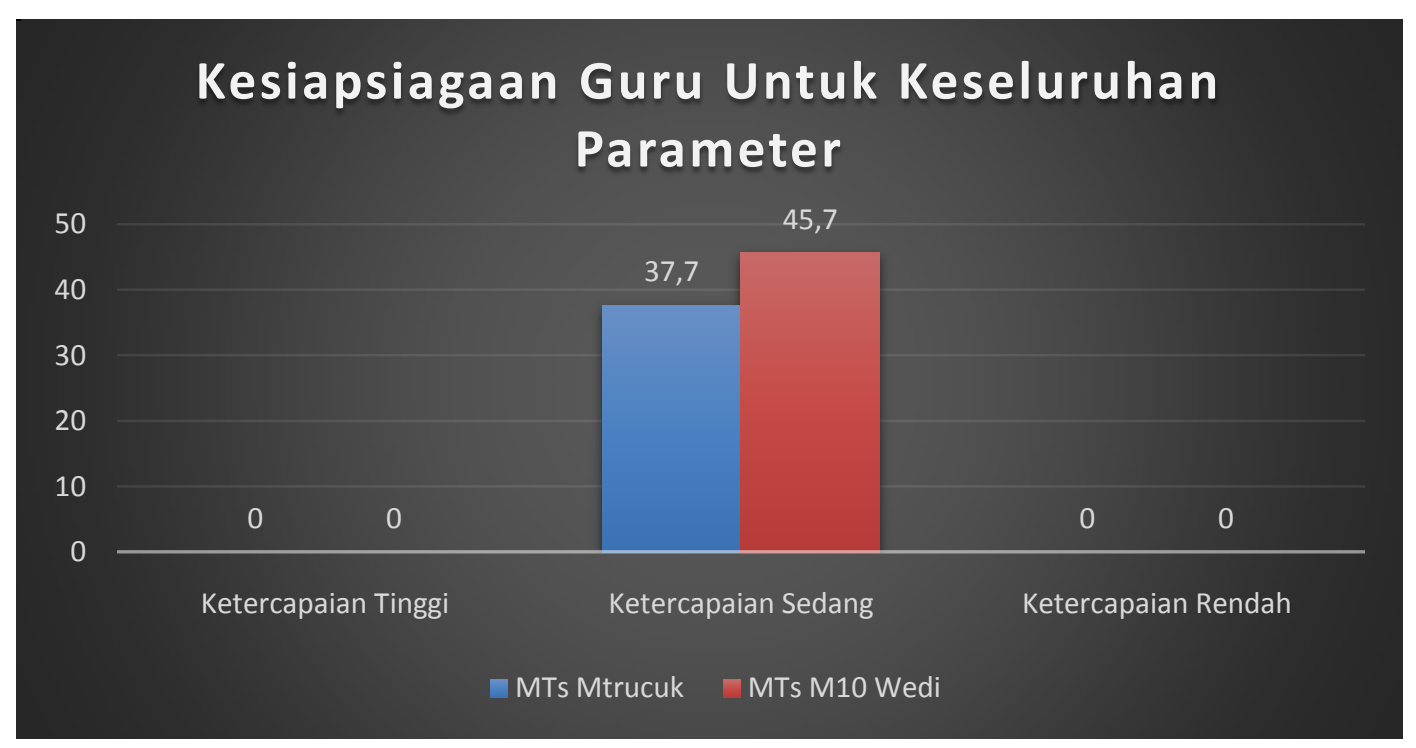

\section{Gambar 5. Grafik Kesiapsiagaan Guru untuk Keseluruhan Parameter}

Gambar 5 mendeskripsikan kesiapsiagaan guru untuk keseluruhan parameter di MTs M Trucuk dan MTs M 10 Wedi tahun2019. Berdasarkan data diatas kesiapsiagaan guru MTs M Trucuk memiliki nilai 37,7\% dan MTs M 10 Wedi memiliki nilai 45,7\% dengan ketercapaian sedang. Kesiapsiagaan guru MTs M 10 Wedi memiliki nilai yang lebih tinggi dibandingkan dengan kesiapsiagaan guru MTs M Trucuk, dengan selisih nilai sebesar 8\%. Dengan demikian sekolah siaga yang ada dapat memberikan dampak yang positif terhadap kesiapsiagaan guru yang ada. 


\section{SIMPULAN}

Berdasarkan hasil penelitian dan pengujian analisis data, maka diambil beberapa Kesimpulan sebagai berikut:

1. Kesiapsiagaan secara keseluruhan dari kedua sekolah memiliki hasil yang hampir sama dari guru maupun siswa pada keseluruhan parameter. Kesiapsiagaan guru yang dimiliki MTs M Trucuk dalam kategori ketercapaian tinggi, sedangkan MTs M 10 Wedi juga dalam kategori ketercapaian tinggi. Apabila dilihat dari kesiapsiagaan keseluruha MTs M Trucuk dan MTs M 10 Wedi termasuk dalam kategori ketercapaian tinggi.

2. Kesiapsiagaan secara keseluruhan dari kedua sekolah memiliki hasil yang hampir sama dari guru maupun siswa pada keseluruhan parameter. Kesiapsiagaan siswa yang dimiliki MTs M Trucuk dalam kategori ketercapaian sedang, sedangkan MTs M 10 Wedi juga dalam kategori ketercapaian sedang. Apabila dilihat dari kesiapsiagaan keseluruhan MTs M Trucuk dan MTs M 10 Wedi termasuk dalam kategori ketercapaian sedang.

Dapat diketahui bahwa tingkat kesiapsiagaan pada kedua sekolah masuk dalam kategori tinggi, hal itu dapat dilihat dari grafik hasil perhitungan data kuisioner yang sudah diisi oleh siswa dan guru MTs M Trucuk dan MTs M 10 Wedi.

\section{DAFTAR PUSTAKA}

Firmansyah, I. (2014). Hubungan Pengetahuan dengan perilaku Kesiapsiagaan dalam menghadapi Banjir dan Longsor pada Usia 15-18 tahun di SMA AlHasan Kemiri Kecamatan Panti Kabupaten Jember. Jurnal Hubungan Pengetahuan dengan Perilaju Kesiapsiagaan, 2.

Kresnadewa, P. D. (2006). Permasalahan Industri Kecil Pascagempa Bumi Survei Pada Beberapa Industri di Kabupaten Klaten Jawa Tengah. KINERJA Vol 10, No.2, 163.

Nur, A. M. (2010). Gempa Bumi, Tsunami dan Mitigasinya. Jurnal Geografi Vol 7 No.1 Januari, 67. 
Badan Pusat Statistik Kabupaten Klaten Tahun 2018.

Lipi. 2009 Panduan Mengukur tingkat kesiapsiagaan masyarakat dan komunitas sekolah. Lipi Pres.

Data \& Informasi Bencana Indonesi, Kabupaten Klaten Tahun 2018. 